\title{
PAST IMPERFECT
}

Past Imperfect presents concise critical overviews of the latest research by the world's leading scholars. Subjects cross the full range of fields in the period ca. 400-1500 CE which, in a European context, is known as the Middle Ages. Anyone interested in this period will be enthralled and enlightened by these overviews, written in provocative but accessible language. These affordable paperbacks prove that the era still retains a powerful resonance and impact throughout the world today.

\section{Director and Editor-in-Chief}

Simon Forde, 's-Hertogenbosch

\section{Production}

Ruth Kennedy, Adelaide

\section{Cover Design}

Martine Maguire-Weltecke, Dublin 


\section{The Viking Eastern Baltic}

Marika Mägi

ARChumanities press 
Translated by Piret Ruustal.

Financially supported by institutional research funding IUT (IUT18-8) of the Estonian Ministry of Education and Research.

\section{British Library Cataloguing in Publication Data}

A catalogue record for this book is available from the British Library

\section{(C) 2019, Arc Humanities Press, Leeds}

The author asserts their moral right to be identified as the author of this work.

Permission to use brief excerpts from this work in scholarly and educational works is hereby granted provided that the source is acknowledged. Any use of material in this work that is an exception or limitation covered by Article 5 of the European Union's Copyright Directive (2001/29/EC) or would be determined to be "fair use" under Section 107 of the U.S. Copyright Act September 2010 Page 2 or that satisfies the conditions specified in Section 108 of the U.S. Copyright Act (17 USC §108, as revised by P.L. 94-553) does not require the Publisher's permission.

ISBN (print): 9781641890977

e-ISBN (PDF): 9781641890984

e-ISBN (EPUB): 9781641890991

www.arc-humanities.org

Printed and bound by CPI Group (UK) Ltd, Croydon, CRO 4YY 